\title{
The Estimation of Mangroves Area and Density of Mangroves Changes Use the Remote Sensing Data at Northheast Province of Aceh, Indonesia
}

\author{
Febriandi \\ Lecuture of Geography Department, Faculty of Social Science, Universitas Negeri Padang \\ Email: febriandigeografi@gmail.com
}

\begin{abstract}
The aim of the research to mapping mangrove estimate mangroves area in time series data at the years 2000 , 2005, 2011, and 2015, and looking for density of mangroves changing at the Northeast Province of Aceh. The methodology use data Landsat TM5, OLI TIRS, Administration map, and tools use by ENVI 4.5, ArcGIS 10.1, technical analysis to interpretation mangroves area used the algorithm the maximum likelihood classification, Kernel density to calculate density of mangroves changing. Result of the research. From the estimation of mangrove land with intrepetasi satellite imagery obtained by maximum likelihood algorithma cotton area of mangroves in the study are always varied and changing, change-oriented land areas surrounding existing land use is not mangrove in mangrove areas. Mangrove areas relative change in Kernel density indicated in the model to observe the point of incidence of the changes experienced more change in the frequency changes in the form of multi-time repeated changes of the time period, and changes in the relatively small area that is always on changing every time calculations.
\end{abstract}

Keywords: Mangrove, Remote Sensing, Changes Use

\section{Introduction}

Mangrove such characteristic of costal vegetation. Mangrove ecosystems are scattered throughout the tropical and subtropical oceans (Nybakken, 1998; Krauss, Lovelock, McKee, Hoffman, Ewe, Sousa, 2008). Mangrove vegetation growing only in sheltered beach of wave motion; when a coastal state otherwise, the seeds are not able to grow perfectly and dropping roots. These beaches are in along side the islands are sheltered from the wind, or a series of islands or on islands with a land mass behind the coral reef offshore shielded (Nybakken, 1998). Mangrove ecosystem in the coastal areas that is the junction between the terrestrial and marine ecosystems. The scope of this ecosystem is divided into two, namely 1) dry or submerged in sea water, and is still influenced by the physical properties of the sea such as tides, waves and waves and sea water intrusion; 2) towards the sea covers the marine waters and are influenced by natural processes occurring on land such as sedimentation and flow of freshwater from rivers including those resulting from human activities on land such as deforestation, waste disposal, settlement expansion and intensification of agriculture. However, mangrove forests are dynamic ecosystems and has the ability to recover quickly if the conditions of geomorphology and hydrology and habitat composition is not altered by the user (Martinuzzi, Gould, Lugo and Medina, 2009, Whardani, 2011).

Edmun (2002) Mangrove areas are often difficult to reach and equally difficult to penetrate. Thus, field survey of mangroves is logistically demanding particularly where the areas are large. Remote sensing offers a very cost-effective method of extending limited field survey to map large areas of mangroves. Mangrove habitat maps are primarily used for three management applications: resource inventory, change detection and the selection and inventory of aquaculture sites. Analysis a range of remote sensing approaches 
to mangrove mapping and the quantitative assessment of mangrove resources using satellite and airborne imagery, and make recommendations as to the most effective options. Image processing techniques appropriate for mangrove mapping can be categorised into five main types: 1) visual interpretation, 2) vegetation indices, 3) unsupervised classification, 4) supervised classification, and 5) principal components analysis of band ratios. The image processing method (5) based on taking ratios of different red and infrared bands and using these as inputs to principal components analysis (PCA) generated the most consistently accurate maps of mangroves.

\section{Method}

The study area have choice at costal environment northeast Province of Aceh. The one of all location include at northeast costal environment Province of Aceh Langsa City, the government developing the mangrove area to be tourism object, and many people choosing the location to be destination at ecological tourism object. Many factor will influence land use change around mangrove area. In the other place many people changes the mangrove area to be farming area such cultivate area like as rice and developing to fishpond surrounding of mangrove. At The northeast costal environment Province of Aceh, some location at mangrove area many people developed area and had using the land to other function, and the mangrove always be a target to developing area, like the farming area and tourism. Classification is the process of identifying image pixels with similar properties, organizing them into groups and assigning labels (e.g. habitat names) to those groups. The end product of classification is a map of habitats or other features of interest. Many Method exist to achieve this, ranging in complexity, cost and time. The simplest involves an analyst tracing the boundaries of habitat patches on an aerial photograph with a pencil. A more sophisticated approach involves the use of digitising tablets to draw polygons around different habitats but, like any visual interpretation or photo-interpretation method, still suffers from the subjectivity of the operator. For digital imagery by contrast, a computer can be instructed to classify an image objectively using clearly defined rules. There are two main approaches to classifying multispectral digital images unsupervised and supervised classification (Edmun, 2000). Multispectral classification of image data which identifies statistically-based clusters to group pixels together into different classes:

- Training: the process of defining the spectral envelope of each class. A seagrass class, for example, may bedefined by minimum and maximum pixel values in three wavebands, thus defining a 3dimensional spectralenvelope that is cubic in shape. This simple statistical description of the spectral envelope is termed the'signature'.

- Signature evaluation: signatures derived from the above are checked for representativeness of the habitats they attempt to describe and to ensure a minimum of spectral overlap between signatures of differenthabitat. Signatures may need to be deleted, merged or manipulated

- Decision making: the process of actually sorting all image pixels into classes (defined by signatures) using mathematical algorithms called 'decision rules'. This stage is sometimes referred to as classification though, in practice, training and signature evaluation are integral parts of the whole process.

This is the most sophisticated of the common parametric decision rules because it takes into account the most variables. Both the variability of classes and the probability of a pixel belonging to each class are taken into account in calculating the distance between a candidate pixel and the mean of all classes. The basic equation for this decision rule assumes that the probabilities of a pixel being in each class are equal. However if the analyst has a priori reasons to believe that these are not equal then the probabilities can be weighted - in other words if there are good reasons to believe that a pixel is twice as likely to be sand as seagrass then the sand probability can be weighted to twice that of seagrass. Maximum decision rule with 
weighted probabilities is known as a Bayesian decision rule - readers interested in the mathematics of the Bayesian rule are referred to Hord (1982) Edmun (2002).

Where:

$$
g_{i}(x)-\ln p\left(w_{i}\right)-1 / 2 \ln \left[\Sigma_{i}\right]-1 / 2\left(x-m_{i}\right)^{2} \Sigma_{2}^{-1}\left(x-m_{i}\right)
$$

$i=$ Class

$x=n$-dimensional data (where $n$ is the number of bands)

$p\left(w_{i}\right)=$ probability that class $w_{i}$ occurs in the image and is assumed the same for all classes

$\left|\Sigma_{i}\right|=$ determinant of the covariance matrix of the data in class $w_{i}$

$\Sigma_{i}^{-1}=$ its inverse matrix

$m_{i}=$ mean vector

Sources: Richard (1999) ENVI Help 5.0

Kloog (2009); Roni (2014) the distribution pattern more ease to understanding if do representation in geography information system. One of tools in geography information system can to use the Kernel Density method. Kernel density where mathematic function then developing in spatial analysis to measuring distribution and density of point in a radius. Kernel density the model to measure density of point un parameter. The Kernel Density in the research have use to understanding density of locacation of mangroves changing. When the many location mangroves change, and the location will do explaining by one point the location mangroves changing. All of location mangroves changing will estimate density of mangroves changing use the algorithm Kernel Density. For knows the accuracy data result of imagery transformation and classification by the independent data, there use by confusion matrix, that such method for to account by the accuracy data result of imager analysis.

Where:

$$
\mathrm{MA}=(\mathrm{Xcr} \text { pixel }) /(\mathrm{Xcr} \text { pixel }+ \text { Xo pixel }+ \text { Xco pixel }) * 100 \%
$$

$\mathrm{MA}=$ mapping accuracy

$\mathrm{Xcr}=$ pixel $\mathrm{X}$ correction

$\mathrm{Xo}=$ pixel $\mathrm{X}$ lost to other class (omission)

$\mathrm{Xco}=$ pixel $\mathrm{X}$ from other class (comission)

\section{Results and Discussion}

The results were obtained, more dominant mangrove change in areas close to the activities of human activity, in essence, these changes visible changes in mangrove land into cultivated land fish ponds.

a), Mangroves map 2000

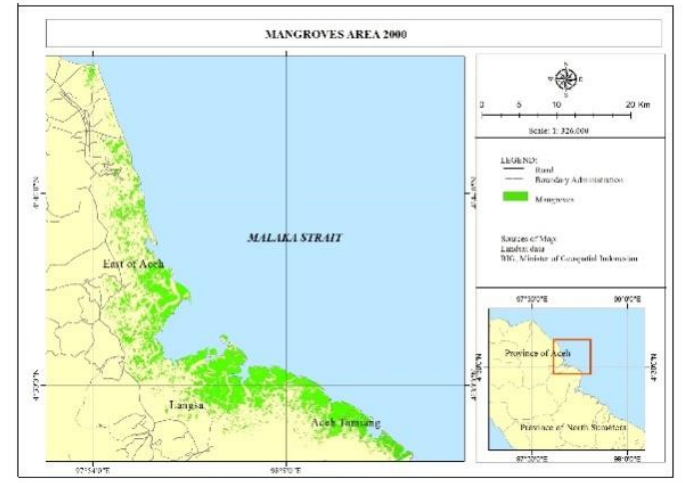

b) Mangroves map 2005

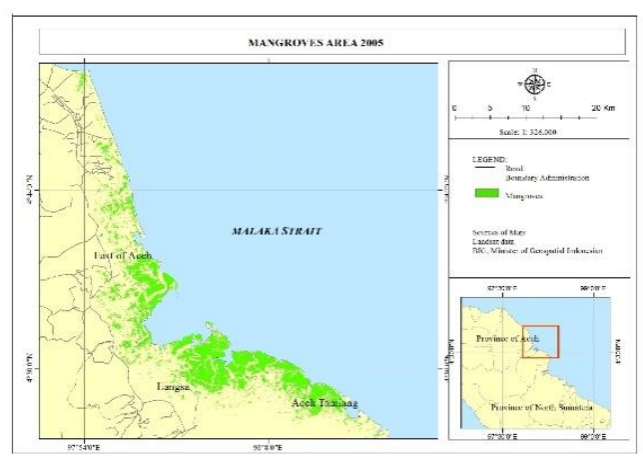


d) Mangroves map 2011

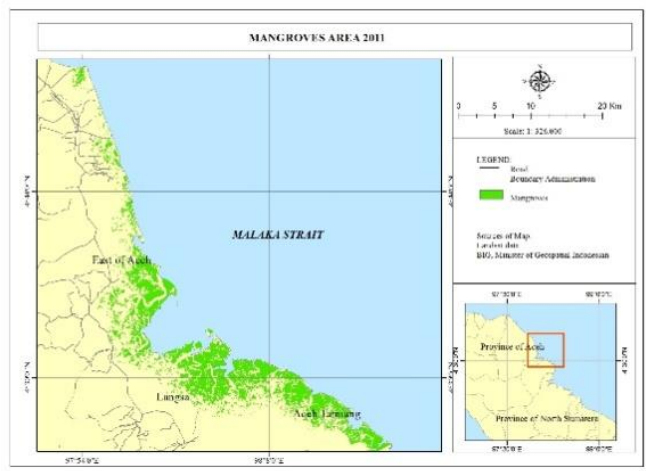

e) Mangroves map 2016

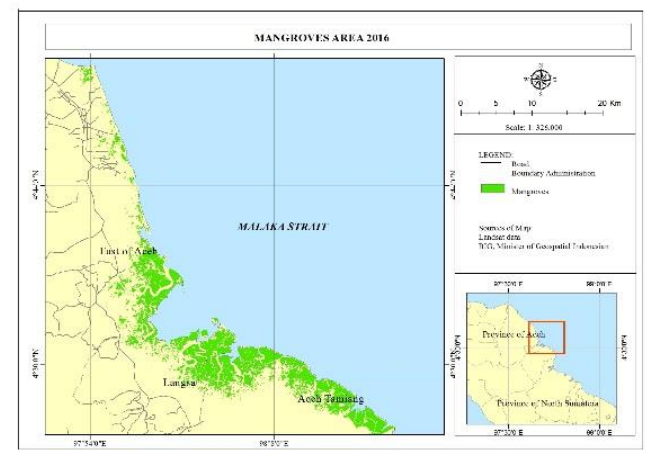

f) Mangroves change

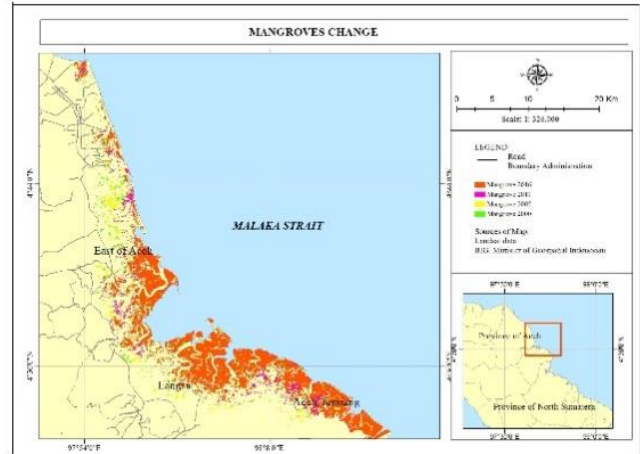

The mangroves area has did estimate and mapping and then calculate to measure the larges area of mangroves. The calculation of mangroves area have presenting in the table 1 . The Interpretation of the image classification used as a vector for easier calculation cotton area of mangrove areas.

Table 1: Estimate Mangroves Area

\begin{tabular}{|l|l|l|}
\hline No & Years & Hectare $(\mathrm{Ha})$ \\
\hline 1 & 2000 & 15138 \\
\hline 2 & 2005 & 14913 \\
\hline 3 & 2011 & 14643. \\
\hline 4 & 2016 & 14273 \\
\hline
\end{tabular}

Sources: Analysis data

From the table of mangroves changes we can look at development of the land use change in the form of mangrove forest area 15138 hectares, in 2000 the land covered with mangrove vegetation area of 14913hectares in 2005, at the 2011 of land area 14643hectares, in 2016 the mangroves area 14273 hectares of mangrove land area and the. The decline in mangrove land area is accompanied by the development of aquaculture function. It can observe the development of pond year after year. Described in land development graph below ponds and mangroves.

\section{Density of mangroves changing}

All of location mangroves area change and conversion to point data the aim to create modeling estimate density of frequency of area changing multi times. The each occurrence of mangrove land use change will be assumed as a form titk incident area change, the purpose of the determination of this point to 
make a change estimation modeling mangrove using the principle of geographic information system logic kernel density.

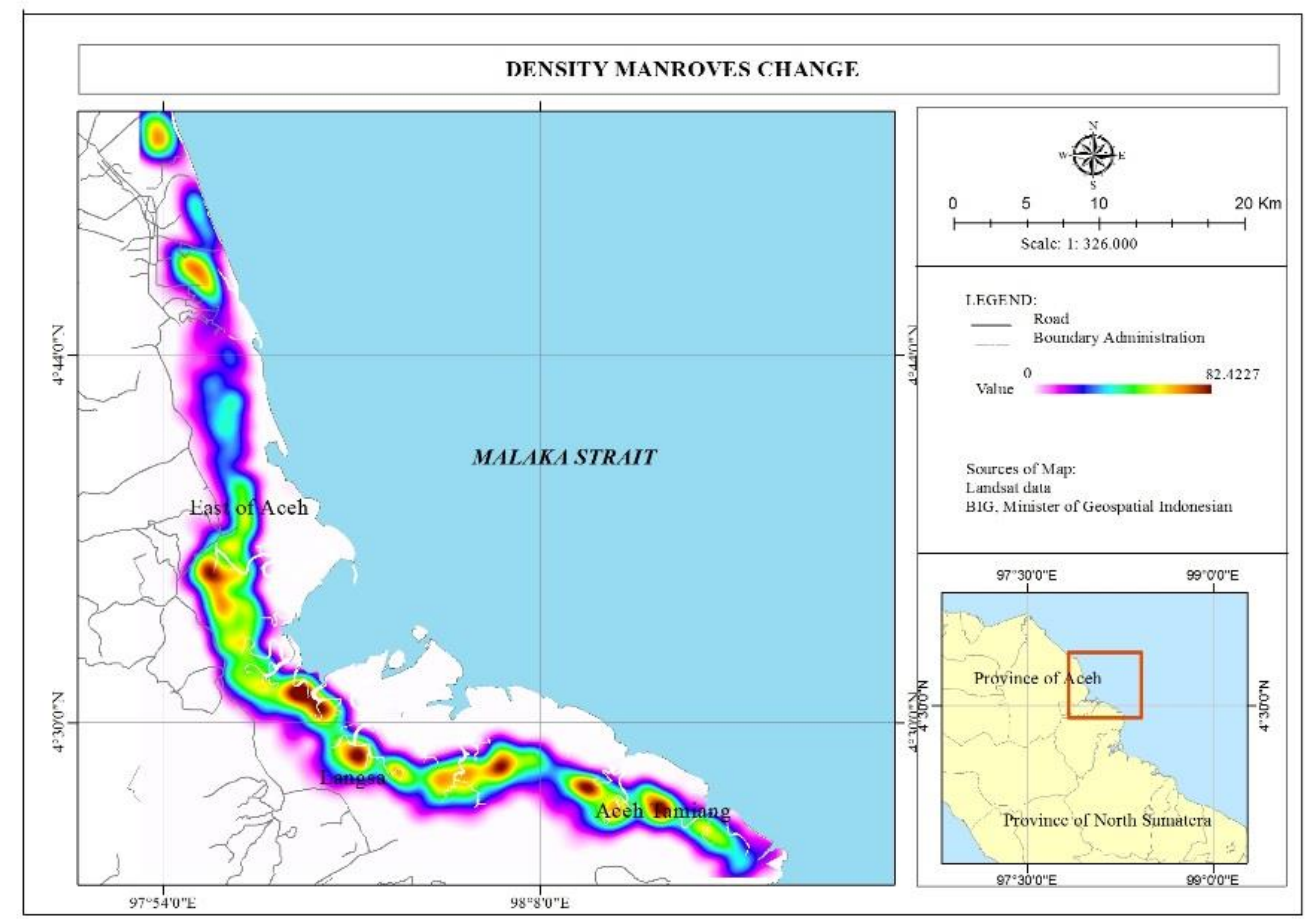

Assumptions of modeling these changes using kernel density at a location experiencing continuous change in each years of research with the relatively small area or a large and distribution locations are assumed to change at one point the location of the change in the point format. Mainly one area that will change conversioninto one point. From the modeling will appear mangrove frequency changes can be observed from the orientation changes mangroves near human activity means that the road network. In this study used 204 samples in accordance with the advice Fitzpatric accuracy (Mc Coy, 2005) completed with the formula he suggested.In addition interpretation of data with high-resolution images. The images high resolution had used for to independent data to measure accuracy.

Table 2: Accuracy Assessment

\begin{tabular}{|l|c|}
\multicolumn{2}{|c|}{ Table 2: Accuracy Assessment } \\
\hline Overall accuracy (\%) & Maximum Likelihood \\
\hline Sources: Analysis data
\end{tabular}

\section{Conclusion}

From the estimation of mangrove land with intrepetasi satellite imagery obtained by maximum likelihood algotima cotton area of mangroves in the study are always varied and changing, change-oriented land areas surrounding existing land use is not mangrove in mangrove areas. Mangrove areas relative change in Kernel density indicated in the model to observe the point of incidence of the changes experienced more change in the frequency changes in the form of multi-time repeated changes of the time period, and changes in the relatively small area that is always on changing every time calculations. Found area very near to the bay area. accurracy is obtained in the range of which is quite good in and the selection of sample data. 


\section{Reference}

Danoedoro, P. (2012). Introduce Digital Remote Sensing. Andi Yogyakarta. ISBN 978-979-29-3112-9

Edmun, P.G., and J. P. Mumby. (2000). Remote Sensing for Tropical Costal Management. UNESCO PUBLISHING. ISBN 92-3-103736-6

Forestian, O. (2011). Estimasi Biomassa dan Kerapatan Vegetasi Mangrove Menggunakan Data Landsat ETM+. Fakultas Kehutanan Institut PertanianBogor(1-62)

Herwindya, A. Y dan E. Winarti. (2014). Analisis Manfaat Mangrove dan Terumbu Karang Terhadap Lingkungan Pesisir Serta Implikasinya Pada Pendapatan Nelayan (Studi Emperik Pesisir Pantai Demak). Jurnal Ekonomi Manajemen dan Akuntansi. No. 36 / Th. XXI / April 2014. Universitas Indonesia. Depok

Huette, A.,C. Justice, dan W. Van Leeuwen. (1999). Modis Vegetation Index.AlgoritmaTheorical Basic Document

Lillesand M T and Kiefer W Ralph. (2004). Remote Sensing and Image Intrepetation. United States of America.

Lembaga Penerbangan dan Antariksa Nasional (LAPAN). (2015). Buku Pedoman Teknik Pengolahan data Pengindraan Jauh Landsat 8 Untuk Mangrove. Jakarta

Lillesand, T.M dan R. W. Kiefer. (1990). Pengindraan Jauh dan Intepretasi Citra. Terjemahan. Gajah Mada University Press. Yogyakarta

Mc Coy M. Roger. (2005). Field Method in Remote Sensing. The Guildford Press:New York London

Mulyadi, E., O. Hendriyanto, dan N. Fitriani. (2010). Konservasi Hutan Mangrove Sebagai Ekowisata. Jurnal Ilmiah Teknik Lingkungan Vol.1 Edisi Khusus

Novianty, R., S. Sastrawibawa dan J.D. Prihadi. (2011). Identifikasi Kerusakan dan Upaya Rehabilitasi Ekosistem Mangrove Di Pantai Utara Kabupaten Subang

Phihastuti, U. (2009). Pemanfaatan Sistem Informasi Geografis (GIS) dalam Pemetaan Sebaran Mangrove di Pesisir Cirebon Jawa Barat. UPI. Bandung

Puspita, L et al. (2005). Lahan Basah Buatan di Indonesia. Wetlands International - Indonesia Programme. Bogor

Rahmi, J. (2009). Hubungan Kerapatan Tajuk dan Penggunaan Lahan Berdasarkan Analisis Citra Satelit dan Sistem Informasi Geografis di Taman NasionalGunungLeuser. Skripsi Departemen Kehutanan Fakultas Pertanian Universitas Sumatera Utara Medan(1- 57)

Roni, S.H. (2014). Analisis Pola Persebaran Penyakit Tuberkulosis Paru (Tb Paru) Di Kecamatan Koto Tangah Kota Padang Tahun 2012. Skripsi. Geografi. Universitas Negeri Padang

Refrial, R.A., B. Koswara dan H. Hamdani. (2012). Analisis Perubahan LuasanHutan Mangrove Di Jawa Barat Dengan Menggunakan Data Citra Satelit. Universitas Padjarjaran. Bandung

Santoso, U. (2007). Masalah Lingkungan Dan Solusinya Di Propinsi Bengkulu, Bangka Belitung Dan Lampung. PusatPenelitianLingkunganHidup. Diskusi Pusat Studi Lingkungan Hidup dengan Lembaga Pengelola Lingkungan Hidup Daerah. Universitas Negeri Bengkulu

\section{Febriandi}

Lecuture of Geography Department, Faculty of Social Science, Universitas Negeri Padang

Email: febriandigeografi@gmail.com 